\title{
PENULISAN ARTIKEL ILMIAH HASIL PENELITIAN TINDAKAN KELAS
}

\author{
Slameto \\ slameto_usw@yahoo.com \\ Program Pendidikan Guru Sekolah Dasar \& PPS-MP, FKIP -UKSW
}

\begin{abstract}
ABSTRAK
Laporan PTK merupakan pernyataan formal tentang hasil penelitian yang dibuat oleh seseorang/guru yang diharuskan untuk melakukan hal itu. Tujuan menulis laporan secara sederhana adalah untuk mencatat, memberitahukan, dan merekomendasikan hasil penelitian yang berupa temuan baru dalam bentuk teori, konsep, metode, dan prosedur, atau permasalahan yang perlu dicarikan cara pemecahannya. Hasil penelitian formal dipublikasikan melalui seminar, pengkajian ulang, analisis kebijakan, pendiseminasian dan sebagainya; Salah satu bentuk yang paling populer adalah artikel. Secara umum, isi artikel hasil penelitian meliputi: judul artikel, nama penulis, abstrak dan kata kunci, pendahuluan, metode, hasil dan pembahasan, simpulan dan saran, serta daftar rujukan.
\end{abstract}

Kata kunci: Laporan PTK, Artikel Ilmiah, Pendahuluan, Metode, Hasil

Penelitian dan Pembahasan, Simpulan dan Saran.

\section{PEMBUKA}

Artikel ilmiah adalah karya tulis yang diharap, ditunggu-tunggu dan diterima oleh komunitas ilmiah. Artikel ilmiah umumnya adalah laporan hasil penelitian yang ditulis dan dipublikasikan dalam seminar maupun dalam jurnal ilmiah. Namun, tidak jarang artikel ilmiah juga merupakan hasil perenungan atau pemikiran mendalam dalam upaya pengembangan suatu bidang ilmu tertentu.

Isi artikel ilmiah harus orisinal. Temuan hasil penelitian yang disajikan harus benar- benar baru, ataupenyempurnaan dari temuan-temuan yang telah lebih dulu ditemukan pihak lain. Jika merupakan hasil pemikiran atau perenungan harus pula merupakan pemikiran yang menawarkan gagasan atau konsep-konsep baru.

Artikel ilmiah tidak selalu harus menyajikan koleksi data-data, melainkan diutamakan atau dituntut menyajikan analisis dan interpretasi intelektual atas datadata. Artikel ilmiah tidak diseyogyakan menggunakan kata atau kalimat yang berisi analogi dan metafora. Artikel ilmiah mengutamakan penyajian fakta-fakta yang dipaparkan secara singkat dan jelas. Artikel ilmiah harus mengandung 
informasi sebanyak-banyaknya, diungkapkan dengan kata dan kalimat yang sedikit-dikitnya. Oleh karena itu, artikel ilmiah harus sejelas dan sependek mungkin.

Hal penting yang harus diperhatikan penulis adalah, karya ilmiah dirancang bukan untuk tujuan hiburan atau entertaintment, melainkan untuk mengkomunikasikan temuan ilmiah baru. Secara singkat, artikel ilmiah dapat didefinisikan sebagai berikut.

1. Publikasi pertama hasil penelitian atau hasil perenungan pemikiran ilmiah yang orisinal.

2. Disajikan dalam bentuk pemaparan yang memungkinkan pembaca melakukan pengecekan simpulan, melakukan verifikasi dan pengulangan eksperimen, jika di dalam artikel menjelaskan tentang hasil suatu eksperimen.

3. Dimuat dijurnal ilmiah atau dokumen lain yang tersedia dalam komunitas ilmuwan, atau dipresentasikan dalam suatu forum ilmiah di kalangan komunitas ilmuwan sejenis.

Ide-ide yang diajukan di dalam artikel ilmiah harus disampaikan secara jelas dan logis. Perpindahan dari satu ide ke ide lain harus mengalir lancar. Proses pengembangan ide seperti itu diperlukan agar menarik pembaca untuk tetap setia membaca sampai titik terakhir artikel itu. Pembaca diupayakan agar tidak hanya setia membaca sampai selesai, tetapi terinspirasi untuk mengaplikasikan atau menerapkan ide-ide yang diinformasikan dalam artikel itu. Motivasi penulisan, pemikiran, dan perancangan penelitian dan perenungan harus dilaporkan lengkap, agar dapat mempengaruhi pembaca menerima atau menolak hasil penelitian yang dipaparkan dalam tulisan. Jika pengetahuan hasil penelitian yang ditulis di dalam artikel itu dapat bertahan dari segala macam kritik, maka ia diterima sebagai bagian dari tubuh ilmu pengetahuan, sampai muncul temuan baru yang lain, yang mampu menyangkal hasil penelitian itu.

\section{Tujuan/fungsi penulisan artikel ilmiah hasil penelitian}

Laporan PTK merupakan pernyataan formal tentang hasil penelitian yang dibuat oleh seseorang atau badan yang diperintahkan untuk melakukan hal itu. Tujuannya adalah untuk mencatat, memberitahukan, dan merekomendasikan hasil penelitian. Skripsi juga merupakan laporan hasil penelitian yang berupa temuan baru dalam bentuk teori, konsep, metode, dan prosedur, atau permasalahan yang perlu dicarikan cara pemecahannya. Namun untuk mengimplementasikannya memerlukan waktu yang cukup. 
Hasil penelitian formal bisa dipublikasikan melalui seminar, pengkajian ulang, analisis kebijakan, pendiseminasian dan sebagainya. Salah satu bentuk yang paling populer adalah Artikel atau Karya Ilmiah. Karya tulis ilmiah atau dalam hal ini laporan penelitian pada lazimnya disusun dalam bentuk yang sesuai dengan maksud dilakukannya panelitian. Secara umum, alasan atau maksud dilakukannya penelitian yang hasilnya disajikan dalam bentuk karya tulis ilmiah dapat dibedakan antara lain:

1) Untuk penulisan karya akademik dalam rangka memperoleh gelar tertentu, seperti: skripsi untuk gelar sarjana (S1), tesis untuk magister (S2), ataupun disertasi untuk gelar doktor (S3), dan

2) Untuk kepentingan lainnya, seperti karya tulis ilmiah yang dibuat untuk kepentingan umum, yang biasanya dimuat dalam suatu jurnal.

Oleh sebab itu, bentuk-bentuk karya tulis ilmiah dapat digolongkan dalam tiga macam, yaitu: karya akademik, karya profesional dan artikel ilmiah. Dalam uraian ini hanya akan dibahas bentuk yang ke-3 yaitu artikel ilmiah.

Artikel ilmiah, yaitu suatu tulisan yang bersumber dari laporan hasil penelitian dengan maksud untuk kepentingan publikasi yang dimuat pada jurnal ilmiah. Setelah peneliti selesai membuat laporan hasil penelitian yang telah dilakukannya, lazimnya ia juga membuat ringkasan dari laporan penelitiannya itu. Selanjutnya, untuk keperluan publikasi-khususnya untuk pemuatan pada jurnal ilmiah, peneliti dapat menyusun artikel ilmiah yang bersumber dari laporan penelitiannya itu.

\section{KIAT MENULIS ARTIKEL ILMIAH HASIL PENELITIAN UNTUK PUBLIKASI JURNAL}

Secara umum, lazimnya artikel ilmiah itu menganut sistematika sebagai berikut: Judul: ditulis lengkap, informatif, tidak terlalu panjang tapi juga tidak terlalu pendek (antara 5-15 kata) dan memuat variabel-variabel yg diteliti atau kata kunci yg menggambarkan masalah yg diteliti. Untuk PTK, Judul artikel berfungsi sebagai label yang menginformasikan inti isi yang terkandung dalam artikel secara ringkas. Pemilihan kata sebaiknya dilakukan dengan cermat agar selain aspek ketepatan, daya tarik judul bagi pembaca juga dipertimbangkan. Judul artikel sebaiknya tidak lebih dari 15 kata. Kiatnya: Sisipkan kata tugas atau kata hubung, untuk menghasilkan judul yang efektif; Jangan terlalu mudah menggunakan "studi kasus" jika memang bukan kasus; Pertimbangkan pencantuman lokasi penelitian jika lokasi itu hanya sekadar lokasi karena akan sangat membatasi implikasi temuan (Rokhman, Taufiqur, 2014). 
Nama Penulis: sebagai pemegang hak kepemilikan atas tulisan, Nama penulis ditulis tanpa gelar akademik atau yg lain apapun, dan nama lembaga tempat bekerja penulis, dan alamat surel (e-mail). Kiatnya: Semua nama yang tercantum harus bertanggung jawab atas isi artikel, Untuk penulis yang berstatus mahasiswa, alamat pertama yang harus ditulis adalah nama perguruan tinggi tempat studi, Jangan menyingkat nama belakang agar tidak menyulitkan, dasar pengacuan oleh peneliti lain(Rokhman, Taufiqur, 2014).

Abstrak berisi pernyataan ringkas dan padat tentang ide-ide yang paling penting: masalah, tujuan penelitian, prosedur/metode, ringkasan hasil, simpulan dan saran.Ditulis dalam 1 paragraf (kecuali ditentukan lain). Harus utuh, menggambarkan esensi isi keseluruhan, dan terjemahan dalam bahasa Inggris. Untuk PTK, berisi pernyataan yang mencerminkan ide-ide atau isu-isu penting di dalam artikel. Untuk artikel hasil penelitian, prosedur penelitian (untuk penelitian kualitatif termasuk deskripsi tentang subjek yang diteliti), dan ringkasan hasil penelitian, tekanan diberikan pada hasil tindakan penelitian. Panjang abstrak 50-100 kata, dan ditulis dalam satu paragraf. Kiatnya: Latar belakang cukup 1 kalimat dan dapat dilanjutkan dengan pernyataan tujuan penelitian; Pendekatan atau metode yang dipilih: ringkas; Fokus pada temuan penting dan implikasi hasil temuan; Tidak ada singkatan yang tidak dijelaskan terlebih dulu; Tidak mengacu tabel atau gambar serta pustaka acuan; Abstrak benar menurut kaidah bahasa Inggris(Rokhman, Taufiqur, 2014).

Kata Kunci dipilih yang dapat berfungsi sebagai alat penelusur; Mampu mencerminkan konsep yang terkandung dalam naskah. Untuk PTK, Kata kunci adalah kata pokok yang menggambarkan daerah masalah yang dibahas dalam artikel atau istilah-istilah yang merupakan dasar pemikiran gagasan dalam karangan asli berupa kata tunggal atau gabungan kata. Jumlah kata kunci sekitar 5 kata/frasa. Perlu diingat bahwa kata kunci tidak hanya diambil dari kata-kata yang sudah ada di dalam judul artikel. Kata kunci sangat bermanfaat bagi pihak lain yang menggunakan mesin penelusuran pustaka melalui jaringan internet untuk menemukan karya seseorang yang sudah dipublikasikan secara online. Kiatnya: Kata kunci tidak selalu berupa kata tunggal, kata kunci bukan kata biasa tetapi biasanya istilah, urutkan kata kunci berdasarkan abjad, gunakan 4-5 kata kunci, urutkan kata kunci dari yang paling penting ke yang kurang penting (Suminar, 2012).

Pendahuluan yg menyajikan kajian pustaka beserta rujukan yg proporsional, pembahasan dengan ringkas, padat dan langsung mengena masalah yg diteliti menyangkut landasan teorinya, historisnya, atau yg lain yang mengarah ke 
rumusan masalah, rencana pemecahan dan diakhiri dengan tujuan dan manfaat penelitian. Untuk PTK, bagian ini menyajikan kajian pustaka yang berisi paling sedikit tiga gagasan: (1) latar belakang masalah atau rasional penelitian, (2) masalah dan wawasan rencana pemecahan masalah, (3) rumusan tujuan penelitian (dan harapan tentang manfaat hasil penelitian). Sebagai kajian pustaka, bagian ini harus disertai rujukan yang dapat dijamin otoritas keilmuan penulisnya. Kajian pustaka disajikan secara ringkas, padat dan mengarah tepat pada masalah yang diteliti. Aspek yang dibahas dapat mencakup landasan teoretis, segi epistemologis/historis, atau segi lainnya yang dianggap penting. Latar belakang atau rasional hendaknya dirumuskan sedemikian rupa, sehingga mengarahkan pembaca ke rumusan penelitian yang dilengkapi dengan rencana pemecahan masalah dan akhirnya ke rumusan tujuan. Manfaat penelitian merupakan paparan tentang sumbangan apa dengan dilakukannya penelitian tindakan kelas ini? Kiatnya: deskripsikan Pendahuluan secara umum di awal paragraph, biasanya dikaitkan dengan isu-isu global dan ilmiah, dilanjutkan dengan background yang lebih spesifik. Deskripsikan permasalahan yang akan diselesaikan kaitannya dengan Pendahuluan. Deskripsikan letak kebaruan dari teknologi yang digunakan untuk menyelesaikan permasalahan (Istadi, 2007). Letak kebaruan atau kontribusi baru terhadap ilmu pengetahuan harus dibuktikan dengan perbandingannya dengan teknologi yang sudah ada, sehingga sangat perlu refernsi artikel jurnal yang mutakhir. Bagian akhir Pendahuluan dilengkapi dengan tujuan spesifik dari artikel yang ditulis beserta manfaatnya.

Metode yg menyajikan bagaimana penelitian itu dilakukan: lokasi, subjek atau populasi dan sampel, instrumen pengumpul data beserta kualitasnya, rancangan penelitian, cara penggalian data, dan teknik analisis data beserta keabsahannya(Istadi, 2007). Untuk PTK, Pada bagian metode disajikan bagaimana penelitian tindakan kelas dilaksanakan. Uraian disajikan dalam beberapa paragraf tanpa atau dengan sub-bagian. Yang disajikan pada bagian ini hanyalah hal yang pokok saja. Isi yang disajikan berupa siapa sumber datanya (subjek penelitian), bagaimana tindakan dilakukan dan data dikumpulkan (instrumen dan rancangan penelitian), dan bagaimana data dianalisis (teknik analisis data) dan validasinya. Apabila di dalam pelaksanaan penelitian ada alat dan bahan yang digunakan, maka spesifikasinya perlu disebutkan. Kiatnya: Deskripsikan bahan-bahan penelitian secara detil, bila perlu cantumkan merk dan kemurnian dari bahan-bahan yang digunakan. Prosedur penelitian disampaikan dalam bentuk cerita. Deskripsikan prosedur atau metode secara jelas dan berurutan sehingga dapat menjamin prosedurnya diulang dengan hasil yang relatif sama oleh pembaca. Metode penelitian dan metode statistik yang digunakan harus scientific. Jika ada optimasi, 
gunakanlah metode optimasi yang scientific dan memperhatikan interaksi antarvariabel. Gambar rangkaian peralatan harus dideskripsikan dengan jelas. Metode penelitian harus bisa menyelesaikan permasalahan (Istadi, 2007).

Hasil sebagai bagian utama artikel mmenyajikan analisis data sebagai hasil bersih, (tidak memuat proses analisis dan proses pengujian hipotesis serta pembandingan koefisien statistik hasil analisis dengan tabel statistik) yang bisa disajikan dalam tabel atau grafik untuk memperjelas penyajian hasil secara verbal kemudian diberi komentar atau dibahas; apabila hasil cukup panjang bisa disajikan dengan sub-bagian, tetapi bila terlalu pendek digabung dengan pembahasan. Untuk PTK, bagian ini menyajikan secara singkat pelaksanaan tindakan sesuai kegiatan dalam setiap siklus yg dilakukan (termasuk hasil observasi dan refleksi), hasil analisis data terhadap variabel yang diperbaiki/ ditingkatkan. Paparkan juga perkembangan hasil dari siklus satu ke siklus berikutnya. Hasil analisis dapat disajikan dalam bentuk grafik atau tabel untuk memperjelas penyajian hasil secara verbal dengan penjelasan secara singkat.Kiatnya: Tampilkan data hasil penelitian dalam bentuk grafik atau tabel, mana yang lebih tepat, pilih salah satu apakah dalam bentuk grafik atau tabel, tidak boleh duplikasi antara grafik dan tabel.Grafik/gambar biasanya dipresentasikan dalam file jenis TIFF (.tif), JPEG (.jpg). atau Postcript (.eps), satu file per gambar. Kualitas grafik harus jelas dan baik, sehingga ketika diedit di jurnal setelah dikecilkan ukurannya, font size tetap dapat terbaca. Tebal garis harus mencukupi. Hasil penelitian harus signifikan dan mempunyai kontribusi baru bagi ilmu pengetahuan serta menyelesaikan permasalahan. Deskripsikan penyelesaian permasalahan secara jelas, (kemudian diskusikan secara lebih mendalam mengapa hal itu terjadi) (Istadi, 2007).

Pembahasan sebagai bagian terpenting dari keseluruhan artikel bertujuan menjawab masalah atau menunjukkan tujuan penelitian dicapai, menafsirkan temuan penelitian denggan teori/kajian pustaka yang ada di pendahuluan dan mengintegrasikan kedalam kumpulan pengetahuan yg telah mapan, dan menyusun teori baru atau memodifikasi teori yg sudah ada; Pembahasan ini juga mengilhami saran yg akan disampaikan kemudian. Untuk PTK, jawaban atas masalah penelitian hendaknya disajikan secara eksplisit. Penafsiran terhadap hasil penelitian dilakukan dengan menggunakan logika dan teori-teori yang ada. Pengintegrasian temuan penelitian ke dalam kumpulan yang ada dilakukan dengan membandingkan temuan itu dengan temuan penelitian yang telah ada atau dengan teori yang ada, atau dengan kenyataan yang ada di lapangan. Pembandingan harus disertai rujukan.Kiatnya: Berdasar deskripsi penyelesaian permasalahan, kemudian diskusikan secara lebih mendalam mengapa hal itu terjadi (Istadi, 2007). 
Bandingkan hasil penelitian atau diskusinya dengan pendapat orang lain atau penelitian sebelumnya (jurnal/prosiding yang terbaru yang terbit 3 tahun terakhir). Pembahasan harus singkat tapi jelas dan ilmiah.

Simpulan dan saran sebagai penutup menyajikan ringkasan dari uraian yg disajikan pada hasil dan pembahasan dengan mengembangkan pokok-pokok pikiran yg merupakan esensi uraian tersebut; Simpulan disajikan dalam bentuk essei, bukan numerik. Saran disusun hanya berdasarkan simpulan dan pembahasan serta bisa mengacu pada tindakan praktis, pengembangan teoretis serta perlunya penelitian lanjutan. Untuk PTK, simpulan harus menjawab rumusan masalah atau tujuan penelitia dan saran harus sesuai manfaat penelitian. Kiatnya:Klaim yang ada di simpulan harus didukung oleh data-data hasil penelitian yang signifikan (jika tidak, biasanya Rejected). Tulislah simpulan seringkas mungkin, Jangan pernah membuat klaim yang muluk-muluk tetapi tidak didukung dengan data yang signifikan.

AcknowledgementTuliskan ucapan terima kasih kepada penyandang dana penelitian. Tuliskan juga ucapan terima kasih kepada yang membantu dengan intens terhadap penelitian yang dilakukan (Istadi, 2007).Kiat:Ucapan terima kasih biasanya ditempatkan pada akhir tulisan sebelum daftar pustaka. Biasanya yang perlu disebutkan adalah penyandang dana. Berikan nomor kontraknya jika ada, karena ini juga nanti sebagai dokumentasi bagi pemberi dana bahwa penelitian yang dibiayai telah dipublikasikan. Ucapan terimakasih juga dapat diberikan kepada perorangan, lembaga atau kelompok yang secara langsung telah memberi bantuan teknis dan saran. Ucapan terimakasih sebaiknya ditulis dengan sederhana.

Daftar Pustaka harus lengkap sesuai dengan rujukan yang disajikan dalam batang tubuh artikel dan sebaliknya. Kiat: Daftar Pustaka/References harus dituliskan sesuai dengan format jurnal dimana artikel akan di-submit-kan. Tuliskan daftar pustaka yang "up to date”, sebaiknya lebih banyak merujuk jurnal termasuk merujuk ke jurnal yang akan di-submit. Gunakan system rujukan "numbering” atau "Author, year", harus konsisten. Semua pustaka yang dirujuk di teks harus didaftarkan di daftar pustaka, demikian juga sebaliknya. References harus ditulis sesuai format jurnal dimana artikel akan disubmitkan (Istadi, 2007).Untuk itu, penulis perlu mencermati lebih dahulu format seperti apa yang harus diikuti sebelum mulai menulis/menyunting artikel ilmiahnya.

\section{Bahasa yang Digunakan}

Dalam penyusunan laporan penelitian sebagai karya ilmiah, hendaknya digunakan ragam bahasa baku. Suriasumantri (1987) berpendapat bahwa dalam tulisan ilmiah, fungsi simbolik lebih ditekankan daripada fungsi emotif dan afektif agar bahasa 
yang digunakan bersifat reproduktif, yakni gagasan yang disampaikan penulis dapat dipahami secara tepat oleh pembacanya.

Laras bahasa yang digunakan dalam laporan penelitian adalah laras bahasa keilmuan. Menurut Dardjowidjojo (1988), ciri-ciri laras bahasa keilmuan mencakupi: (1) wujud bahasa yang haruslah lengkap (afiksasi yang di dalam ragam informal opsional, dalam bahasa ilmiah wajib), (2) kosakata yang dipakai harus utuh, (3) menggunakan tanda baca yang tepat, (4) padat isi, bukan padat kata-kata, (5) adanya ketepatan ungkapan dan ketunggalan arti, (6) pemakaian bahasa bersifat abstrak, (7) banyak ditemukan kalimat pasif (penekanan pada peristiwa), dan (8) adanya kelengkapan unsur kalimat (seperti subjek dan predikat). Sementara itu, menurut Brotowidjoyo (1985), karangan ilmiah antara lain memiliki ciri-ciri (1) objektif, (2) cermat dan tepat, (3) sistematis, dan (4) tidak emotif.

Berdasarkan uraian di atas, tampak dengan jelas bahwa dalam penyusunan laporan harus memperhatikan aspek penalaran, struktur paragraf, struktur kalimat, diksi, dan ejaan (Ejaan Bahasa Indonesia Yang Disempurnakan). Selain itu, harus pula diperhatikan sistematika dan logika keseluruhan tulisan/artikel. Akhirnya usahakan tulisan hasil penelitian betul-betul bebas dari segala bentuk plagiat.

\section{Kiat Sukses}

Harus mempunyai motivasi yang tinggi untuk menulis, mempunyai ambisi dan militansi tinggi, berlatih terus-menerus; Dengan militansi yang tinggi, kesibukan dan lain-lain harusnya tidak menghalangi untuk menulis yang handal \& bermutu; Orientasi pada publikasi, lakukan segera untuk menulis jika mempunyai topik yang menarik, jangan menunda. Menguji hasil karya dalam lomba-lomba, dan jika tulisan ditolak tidak merasa kecewa justru sebaliknya memacu untuk menulis lebih baik!

Hindari 7 hal berikut ini: 1) menulis tanpa melengkapi bagian-bagian pokok, seperti: abstrak, metode, daftar pustaka yang benar-benar dirujuk. 2) mengutip tanpa mencantumkan sumber kutipan. 3) menulis tanpa berempati terhadap pembaca. 4) menulis tanpa referensi yang memadai. 5) asal menulis, 6) mengirim naskah tanpa pengantar atau proposal, dan 7) menolak naskahnya disunting editor atau sakit hati kalau naskah ditolak.

\section{PENUTUP}

Laporan PTK merupakan pernyataan formal tentang hasil penelitian, yang dibuat oleh seseorang/ guru yang diharuskan untuk melakukan hal itu. Tujuan menulis artikel ilmiah hasil penelitian secara sederhana adalah untuk mencatat, 
memberitahukan, dan merekomendasikan hasil penelitian yang berupa temuan baru dalam bentuk teori, konsep, metode, dan prosedur, atau permasalahan yang perlu dicarikan cara pemecahannya.

Secara umum telah dipaparkan tentang kiat-kiat penulisan artikel ilmiah sesuai isi artikel hasil penelitian meliputi: judul artikel, nama penulis, abstrak dan kata kunci, pendahuluan, metode, hasil dan pembahasan, simpulan dan saran, serta daftar rujukan. Dengan jurus sesuai kiat yang sudah dipaparkan ini akan sangat membantu pembaca sukses menerbitkan artikelnya.

Dalam penyusunan artikel ilmiah hasil penelitian hendaknya digunakan ragam bahasa baku. Dalam tulisan ilmiah, fungsi simbolik lebih ditekankan dari pada fungsi emotif dan afektif agar bahasa yang digunakan bersifat reproduktif, yakni gagasan yang disampaikan penulis dapat dipahami secara tepat oleh pembacanya. Laras bahasa yang digunakan laras bahasa keilmuan, yang memiliki ciri-ciri: objektif, cermat dan tepat, sistematis, dan tidak emotif.

Dalam penyusunan laporan, penulis harus memperhatikan aspek penalaran, struktur paragraf, struktur kalimat, diksi, dan ejaan (Ejaan Bahasa Indonesia yang Disempurnakan). Selain itu, harus pula diperharikan sistematika dan logika keseluruhan tulisan/artikel. Akhirnya usahakan tulisan betul-betul bebas dari segala bentuk plagiat.

Agar sukses dalam menulis artikel ilmiah, penulis arus mempunyai motivasi yang tinggi untuk menulis, mempunyai ambisi dan militansi tinggi, berlatih terus-menerus dan menghindari: 1) Menulis tanpa melengkapi bagianbagian pokok, 2) Mengutip tanpa mencantumkan sumber kutipan. 3) Menulis tanpa berempati terhadap pembaca. 4) Menulis tanpa referensi yang memadai. 5) Asal menulis, 6) Mengirim naskah tanpa pengantar atau proposal, dan 7) Menolak naskahnya disunting editor atau sakit hati kalau naskah ditolak.

\section{PUSTAKA ACUAN}

Achmadi, Suminar Setiati. 2012. Swasunting Naskah Artikel Terbitan Berkala Ilmiah. http://jurnalsospol.fisipol.ugm.ac.id/public/pustaka/201204-KH/

Achmadi, Suminar Setiati. 2015. Metode Penulisan Artikel Jurnal Ilmiah.http:// penelitian. gunadarma.ac.id/penelitian2/download/1007982042

Arikunto, S. 2008. Penelitian Tindakan Kelas. Jakarta: Bumi Aksara

Departemen Pendidikan Nasional. 2005. Pedoman Penyusunan Usulan PTK. Jakarta: PPTK dan KPT Dirjen PT 
El-Kabumain, Nasin. t.th. Teknik Menulis Laporan Penelitian Karya Ilmiah.https:// www.academia.edu/6123896/

Fernata, Jefri . 2014. Manfaat Menyusun Karya Ilmiah. http://jefri-fernata. blogspot. co.id/ 2014/03/manfaat-menyusun-karya-ilmiah.html

G.P, Harianto. 2000. Teknis Menulis Artikel. http://pelitaku.sabda.org/ teknis_menulis_artikel

Istadi, 2007. Kiat Menulis Artikel Ilmiah di Jurnal Nasional dan Internasional. Workshop Pengembangan Jurnal Ilmiah Konsursium Ilmu. 20-21 Agustus 2007.

Khoerunnisa, Alias .Tth. Carkarya Ilmiah.https://www.academia.edu/3731823/

Kusmoro. 2008. Prosedur Menyusun Proposal dan Laporan dalam PTK. http://morosukses.blogspot.co.id/2008/07/prosedur-menyusun-proposal-danlaporan.html

Mudasir.2011. Kiat Menjaga dan Mengelola Publikasi Jurnal Secara Berkelanjutan.http://jurnalsospol.fisipol.ugm.ac.id/public/pustaka/201111 LPPM/

Mulyadi, HP. 2007. Laporan Hasil Penelitian Dalam Penelitian Tindakan Kelas. Semarang: LPMP Jawa Tengah

Mulyasari, Anisa. 2015. Karangan Ilmiah.http://anisamulyasari.blogspot.co.id /2015/11/

Nugraha, Hady . 2013. Karya Ilmiah. http://hadynugrahaa.blogspot.co.id /2013/04/ada-berbagai-definisi-tentang-karya.html

Purnama, Asri. 2013. Cara Membuat Karya Ilmiah. http://asripurnama10. blogspot.co.id/2013/06/

Rahmanto, Arif. 2014. Penggunaan Bahasa Indonesia dalam Penulisan Bahasa Ilmiah. http://arifmancunian.blogspot.co.id/2014/10/

Rokhman, Taufiqur. 2014. Workshop Penulisan Jurnal Ilmiah. http:// taufiqurrokhman.com/2014/03/21/

Slameto, 2015. Kiat-Kiat Menulis Artikel Ilmiah dalam Jurnal Nasional /Internasional, Workshop Penulisan Artikel Ilmiah bagi Tenaga Kependidikan UNNES. Semarang, 16/12, 2015.

Suhardjono. 2008. PTK Sebagai Kegiatan Pengembangan Guru. Jakarta: Bumi Aksara 
Supardi, 2008. PTK Beserta Sistematika Proposal dan Laporannya. Jakarta: Bumi Aksara

Wiriaatmadja, R. Metode Penelitian Tindakan Kelas. Bandung: Kerjasama PPS UPI dengan PT Remaja Rosdakarya.

\section{Lampiran}

\section{Evaluasi Kualitatif Karya Ilmiah}

\section{1) Keunggulan Artikel}
a. Informasi: fakta, opini didukung data
b. Analisis: fakta diperiksa dan dihubung-hubungkan
c. Seimbang: opini dibedakan dari fakta, tidak sekadar cerita satu- versi/sisi
d. Keaslian
e. Daya penarik: jujur, menarik, persuasif
f. Relevansi: kewaktuan, menantang atau membenarkan pembaca
g. Kebenaran.

\section{2) Judul \& Abstrak}

a. Judul:Apakah judul yang disampaikan mudah dipahami?Apakah terdapat "kesesuaian" antara judul dan isi karya ilmiah?

b. Abstrak:Apakah abstrak menggambarkan isi tulisan?

\section{3) Tema Sentral \& Permasalahan}

a. Tema Sentral:Apakah tema sentral dirumuskan secara jelas? Adakah keterkaitan antara tema dengan masalah yang dibahas?

b. Identifikasi Masalah:Apakah masalahnya di ungkapkan secara eksplisit dan efektif?Sejauh mana masalah yang digarap relevan dengan state of the art dari disiplin ilmu pendidikan/ pembelajaran?

\section{4) Tujuan \& Manfaat}

a. Tujuan Penelitian:Apakah tujuan penelitian dituliskan secara jelas? Apakah ada keterkaitan tujuan penelitian dengan masalah penelitian?

b. Manfaat Penelitian:Apakah manfaat penelitian dituliskan secara jelas? Apakah manfaat tersebut berupa manfaat praktis atau teoritis? Sejauh mana manfaat tersebut dapat menggambarkan bobot penelitian? 


\section{5) Kerangka, Pustaka, dan Metode}

a. Kerangka Pemikiran:Apakah butir-butir di atas disampaikan secara eksplisit dalam bentuk subjudul?

b. Tinjauan Pustaka:Sejauh mana originalitas dan aktualitas penelitian tersebut?

c. Metode Penelitian:Apakah metode yang dipilih relevan dengan masalah yang disampaikan?Apa yang menjadi dasar pemilihan metode tersebut?

\section{6) Hasil \& Pembahasan}

a. Hasil Penelitian dan Pembahasan:Apakah pembahasan dilakukan secara sistematis? Bagaimana data maupun hasil penelitian disajikan dan diinterpretasikan?Apakah ada alur pemikiran yang logis dalam penyampaian pembahasan?Sejauh mana pembahasan ini sesuai dengan masalah penelitian?Adakah penemuan baru yang disampaikan oleh peneliti?

\section{7) Penarikan Simpulan}

a. Penarikan Simpulan:Apakah simpulan yang diambil didukung oleh data empiris yang telah diinterpretasikan baik kualitatif maupun kuantitatif?Apakah peneliti menggunakan logika deduktif atau induktif dalam menarik simpulannya?Sejauh mana penelitian ini memberikan sumbangan untuk kemajuan ilmu pengetahuan?Apakah peneliti memberikan dorongan untuk melakukan penelitian lanjutan? 